\title{
Associating the Presence of Structural Defects in Dental Enamel with Children's Health History
}

\section{Associando a Presença de Alterações de Estrutura no Esmalte Dentário com Histórico de Saúde na Infância}

\author{
Jessica Crispim*a; Maria Gisette Arias Provenzano ${ }^{\mathrm{a}}$; Adilson Luiz Ramos ${ }^{\mathrm{a}}$; Gabriela Cristina Santin; \\ Marina de Lourdes Calvo Fracasso ${ }^{\mathrm{a}}$
}

${ }^{a}$ Universidade Estadual de Maringá, Stricto Sensu Post-Graduate Program in Integrated Dentistry. PR, Brazil.

*E-mail: jessicabcrispim@gmail.com

\begin{abstract}
The enamel defects, hypoplasia and hypo mineralization, are classified as dental anomalies of structure, being frequently found in deciduous and permanent dentitions, since the permanent teeth and second deciduous molars finish their total mineralization after the age of three. The aim of the present study was to identify the presence of hypo mineralization and/or enamel hypoplasia and to associate it with respiratory problems in infant patients. Of the 90 patients evaluated, it was found that 23 male children $(57.5 \%)$ and 22 female children (44\%) had defects in the structure of tooth enamel. Most children were born by cesarean operation (64.4\%), with no complications during birth (90.0\%), 12.2\% of children had dental anomalies (agenesis, ectopic canine, ankylosis, fusion, conoid tooth, and macrodontia, only 7 children showed an association between dental anomalies and enamel defects. Regarding respiratory problems that occurred up to 3 years of age, $38.9 \%$ had an episode of asthma, bronchitis, sinusitis, rhinitis, or pneumonia, and 55\% had similar results at the current age. There was a positive association (Chi-square tests) between the presence of changes in the structure of tooth enamel and the presence of respiratory problems up to 3 years of age $(p<0.001)$. It is concluded, therefore, that the presence of respiratory problems in early childhood, can interfere in amelogenesis, providing disturbances for the formation of normal enamel, causing defects or irregularities in the surface of the dental enamel, such as hypoplasias and hypo mineralization.
\end{abstract}

Keywords: Dental Enamel Hypoplasia. Dental Enamel. Tooth Abnormalities.

\section{Resumo}

Os defeitos de esmalte, hipoplasia e hipomineralização, são classificados como anomalias dentárias de estrutura, sendo encontrados com frequência nas dentições decídua e permanente, já que os dentes permanentes e segundos molares decíduos finalizam sua total mineralização após os três anos de idade. O objetivo do presente estudo foi identificar a presença de hipomineralização e/ou hipoplasia de esmalte, e associála com problemas respiratórios no paciente infantil. Dos 90 pacientes avaliados, constatou-se que 23 crianças do gênero masculino (57,5\%) e 22 do gênero feminino (44\%) apresentaram defeitos na estrutura do esmalte dentário. A maioria das crianças nasceu de parto cesária (64,4\%), sem complicação no parto (90,0\%), 12,2\% das crianças apresentaram anomalias dentárias (agenesia, canino ectópico, anquilose, fusão, dente conóide e macrodontia), somente 7 crianças apresentaram associação entre anomalias dentárias e defeitos de esmalte. Em relação à problemas respiratórios ocorrido até aos 3 anos de idade 38,9\% apresentaram algum episódio de asma, bronquite, sinusite, rinite ou pneumonia e 55\% apresentaram resultados semelhantes na idade atual. Houve associação positiva (Testes Qui Quadrado) entre a presença de alterações na estrutura do esmalte dentário e presença de problemas respiratórios até os 3 anos de idade ( $p<0,001)$. Conclui-se, portanto, que a presença de problemas respiratórios na primeira infância, podem interferir na amelogênese, proporcionando distúrbios para formação do esmalte normal, causando defeitos ou irregularidades na superfície do esmalte dentário, como hipoplasias e hipomineralizações.

Palavras-chave: Hipoplasia do Esmalte Dentário. Esmalte Dentário. Anormalidades Dentárias.

\section{Introduction}

The prevalence of enamel defects, enamel hypoplasia and hypo mineralization has been scientifically reported in a wide range from $2 \%$ to $60 \%$ of children up to 12 years of age ${ }^{1-4}$.

During odontogenesis, genetic alterations may occur, acquired or of both factors, which may result in some dental anomalies. If there is any change in the initiation and proliferation stages, number anomalies (ageneses or supernumerary) and shape anomalies (gemination and fusion) may occur. At the stage of histodifferentiation, structural anomalies may occur (imperfect hypoplastic and hypo maturated amelogenesis, imperfect dentin genesis, hypoplasia and hypo mineralization). During morpho-differentiation, anomalies of size (microdontia, macrodontia) and anomalies of form (dens in dente, supernumerary roots, accessory cusps, and laceration) may occur. At the apposition stage, structural anomalies (enamel hypoplasia) and shape anomalies (enamel pearls) may occur. In turn, during the calcification stage, anomalies of structure (imperfect amelogenesis) can occur ${ }^{5}$.

Enamel defects do not have a well-defined etiology and are considered to be of multifactorial origin and may be of genetic origin, epigenetics and environmental factors during the long dental development process ${ }^{6,7}$. Among the environmental factors, enamel hypoplasia (he) in permanent teeth may be 
due to dental traumas or prolonged peri radicular infection in its predecessors. Other conditions may be related to its etiology, caused by systemic problems that lead to alterations during amelogenesis, chemical substances ingestion (fluoride, tetracyclines, dioxins, thalidomide); prematurity/low birth weight; severe malnutrition, neonatal hypocalcemia, vitamin D deficiency; bilirubinemia, parathyroid disorders and gestational diabetes; neonatal asphyxiation, severe infections and metabolic disorders ${ }^{3,8,9}$. These changes occur because the dental mineralization starts during the gestational period and is completed after the four years of age, so any complication during this period can cause changes in the enamel formation ${ }^{5}$.

According to some studies, patients with respiratory diseases such as asthma, bronchitis and allergic rhinitis are more likely to develop enamel defects ${ }^{1,8,9}$. Enamel matrix is affected due to low oxygen demand, inhibiting the action of proteolytic enzymes compromising the formation of hydroxyapatite crystal, resulting in hypo mineralized enamel ${ }^{1,11}$.

Clinically, teeth with enamel structure defects due to hypo mineralization present the most porous enamel, which makes them more predisposing to bacterial plaque accumulation, as a result of the difficulty of hygienization caused by high sensitivity, fragility of the affected enamel associated with chewing forces resulting in dental fractures, predisposing to greater involvement by dental caries ${ }^{6,7,12}$.

Some dental anomalies usually appear associated in the same patient, because the same genetic defect can generate several manifestations, such as ageneses, microdontias, macrodontias, ectopias and delay in dental development. Although there are few studies, there is evidence that enamel hypoplasia is associated with other anomalias ${ }^{13}$. Therefore, the diagnosis of any abnormality should alert the professional to the possible development of other associated anomalies.

Although there are several studies on hypo mineralization and enamel hypoplasia, there is still a shortage of studies of association between enamel defects and respiratory problems and their great clinical importance in diagnosis and treatment.

Therefore, considering that identifying the defects in dental enamel is important for diagnostic, clinical, medical and legal purposes, and etiological studies 2, a thorough clinical examination with radiographic examination of this anomaly of dental development is necessary ${ }^{8,14}$. Therefore, this cross-section study aimed to identify the presence of hypo mineralization and/or enamel hypoplasia and to associate it with respiratory problems in infant patients.

\section{Material and Methods}

This cross-sectional study was carried out from a convenience sample, with children aged 5 to 12 , both genders, attending the Children's Dental Clinic of the State University of Maringá, from 2015 to 2017. The inclusion criterion for the present study was to present orthodontic documentation, clinical and radiographic diagnosis of enamel defects (hypoplasia or hypo mineralization). As exclusion criteria, children with some systemic syndrome or metabolic disease, a history of trauma in deciduous dentition, resulting in a sequel to permanent successors dental enamel, enamel defects associated with extensive fractures with great coronary destruction due to dental caries or restoration.

The present study was approved by the Research Ethics Committee of the State University of Maringá - Paraná (0285.0.093.000-11 N - 260/2011) and the informed consent form (TCLE) was signed by the participants' parents.

90 children were included in the study, divided into two experimental groups: Group 1 (GDE) - 45 children diagnosed with enamel defects (hypoplasia and/or hypo mineralization); and Group 2 (GC) - 45 children without enamel defects, according to the same age group, constituting the control group.

In the initial phase of the research, a questionnaire was applied to parents evaluating data regarding the previous history of systemic diseases of the baby's birth (complications at the moment of delivery), health problems up to three years of life (pneumonia, asthma, bronchitis, sinusitis, rhinitis), as well as the child's current health problems (pneumonia, asthma, bronchitis, sinusitis, rhinitis).

Prior to the clinical stage, the evaluator's calibration process was performed, using colored photographs with examples of enamel defects, well-delimited and diffuse opacities on permanent and decent teeth, contained in the health manual, with basic oral presentations by WHO, following the criteria for the diagnosis of the IDF-DDE index ${ }^{15}$. A single evaluator was responsible for evaluating orthodontic documentation and clinical and radiographs evaluation of patients.

The teeth clinical examination for the evaluation of enamel defects was carried out in the premises of UEM Children's Clinic, with the aid of reflector light and dental equipment, with disposable wooden spatulas, complying with biosafety precepts.

During the clinical evaluation, the tooth was considered present when any part of the crown was broken into the oral mucosa and if this partially ruptured tooth presented an enamel defect it was included in this study.

In the clinical evaluation of enamel defects, the recommendation of International Federation for the Development of dental enamel defects (IDF-DDE) was followed $^{15}$, which classifies the changes in: $0=$ normal, enamel translucency; $1=$ delimited opacity, enamel translucency abnormality by a white or discolored area, smoothly delimited in enamel with normal thickness; 2 = opacity, diffuse translucency, normality in enamel thickness, by white and fine lines that follow the perikymata pattern irregular and poorly delimited areas, segmented distribution; 3 = hypoplasia, a defect associated with a reduced enamel thickness. It can occur as holes, slits, grooves and partial or 
total absence of enamel; $4=$ other defects; $5=$ combination of delimited and diffuse opacities; $6=$ combination of welldelimited opacity and hypoplasia; $7=$ combination of diffuse opacity and hypoplasia; $8=$ combination of all three defects.

After the clinical examination, the panoramic radiograph was taken for each patient in order to investigate the presence of other dental anomalies, such as ageneses, supernumerary, ectopia, microdontia, macrodontia and conoid teeth. The radiographs images were performed on a model Orthoralix 9200 device, using Kodak T-Mat G/RA X-ray films, size $15 \times 30 \mathrm{~cm}$ for panoramic X-ray images, with their respective metal film-holder chassis with intensifying screens, Kodak Lanex Médium Extraoral Imaging Screens X-Omat.

For those patients diagnosed with some dental abnormality and with the need for orthodontic intervention, the latter was referred to the child dental clinic of the State University of Maringá (UEM).

Data were included in the statistical program IBM SPSS Statistics ${ }^{\circledR}$, to perform descriptive analysis and the association of variables, using the chi-square test at a significance level of $5 \%$.

\section{Results and Discussion}

Of the 90 patients evaluated, 50 are females (55.6\%), being 23 male children (57.5\%) and 22 female children (44\%) had defects in the structure of tooth enamel. Most of the children were born from cesarean delivery (64.4\%) and no complications at the time of delivery $(90.0 \%)$, only 9 children (10\%) presented problems during delivery, and these problems being lack of oxygen and prolonged delivery.

When analyzed the presence of dental anomalies only $12.2 \%$ of the children presented dental anomalies, such as agenesis, ectopic canine, ankylosis, fusion, conoid tooth and macrodontia. Only 7 children presented an association between dental anomalies and enamel defects.

Regarding respiratory problems occurring up to 3 years of age, $61.1 \%$ of the sample studied presented no complication; 35 children (38.9\%) presented some episode of asthma, bronchitis, sinusitis, rhinitis or pneumonia. Similar results were observed when questioned about respiratory alterations in the current age $(55 \%)$.

When Chi-square tests were performed between the variables presence of changes in the dental enamel structure and the variables studied, only the variable presence of respiratory problems up to 3 years of age presented a positive

association $(\mathrm{p}<0.001)$, data expressed in Table 1 .

Table 1 - Association between the presence of changes in the structure in dental enamel and the variables studied

\begin{tabular}{|c|c|c|c|}
\hline \multirow{3}{*}{ Variables studied } & \multicolumn{2}{|c|}{ Changes in the dental enamel structure } & \multirow{3}{*}{ p-Value } \\
\hline & $\mathbf{N}(\%)$ & $\mathbf{N}(\%)$ & \\
\hline & No & Yes & \\
\hline Gender & & & \\
\hline $\begin{array}{l}\text { Male } \\
\text { Female }\end{array}$ & $\begin{array}{l}17(42.5) \\
28(56.0)\end{array}$ & $\begin{array}{l}23(57.5) \\
22(44.0)\end{array}$ & 0.114 \\
\hline $\begin{array}{l}\text { Type of delivery } \\
\text { Normal } \\
\text { Caesarean } \\
\end{array}$ & $\begin{array}{l}18(56.3) \\
27(46.6)\end{array}$ & $\begin{array}{l}14(43.8) \\
31(53.4)\end{array}$ & 0.255 \\
\hline $\begin{array}{l}\text { Systemic Problems related to Childbirth } \\
\text { Yes } \\
\text { No }\end{array}$ & $\begin{array}{c}4(44.4) \\
41(50.6) \\
\end{array}$ & $\begin{array}{c}5(55.6) \\
40(49.4) \\
\end{array}$ & 0.5 \\
\hline $\begin{array}{l}\text { Respiratory problems up to } 3 \text { years of age } \\
\text { With problem } \\
\text { No problem } \\
\end{array}$ & $\begin{array}{c}9(25.7) \\
36(65.5)\end{array}$ & $\begin{array}{l}26(74.3) \\
19(34.5) \\
\end{array}$ & 0.000 \\
\hline $\begin{array}{l}\text { Respiratory problems at the current age } \\
\text { With problem } \\
\text { No problem }\end{array}$ & $\begin{array}{l}31(62.0) \\
14(35.0)\end{array}$ & $\begin{array}{l}19(38.0) \\
26(65.0)\end{array}$ & 0.10 \\
\hline $\begin{array}{l}\text { Dental abnormalities } \\
\text { No } \\
\text { Yes }\end{array}$ & $\begin{array}{c}41(51.9) \\
4(36.4)\end{array}$ & $\begin{array}{c}38(48.1) \\
7(63.6)\end{array}$ & 0.261 \\
\hline
\end{tabular}

Chi-square test $(\mathrm{P}<0.05)$.

Source: Research data.

Deciduous and permanent teeth begin their formation in the intrauterine period, finishing the maturation of the enamel after birth, and thus systemic problems in early childhood can alter the formation and maturation of dental enamel. In deciduous teeth, the main defects found are fluorosis and hypoplasia, presenting diffuse spots. In the permanent teeth, defects are more variable, the first molars and incisors being the most affected, since complete enamel maturation occurs on average at 3 and 4 years of age, respectively $y^{5,6,14,16}$.

Dental enamel with hypoplasia or hypo mineralization is more porous, more fragile, with greater risk to dental caries and fractures due to chewing efforts. In addition to causing great discomfort due to sensitivity due to the exposure of dental tubules, and a great risk to pulp problems. These enamel 
defects are defined as a complex disease because they involve genetic and systemic factors ${ }^{14,17}$. The treatments vary from sensitivity control, enamel mineralization through the use of fluoride, restoration with glass ionomer cement, composite resins or use of steel or zirconia crowns, and even exodontics, when the tooth is in a more complicated state ${ }^{12}$.

Hypoplasias are the result of sudden and severe aggression during the enamel matrix secretion, being a quantitative defect, while hypo mineralization is the result of aggression during enamel maturation or less severe aggression, but longlasting during enamel matrix secretion, qualitative defect ${ }^{9,5}$.

Ameloblasts are able to deposit the enamel matrix, but due to the low oxygen demand they have difficulties reabsorbing the proteins from the matrix, compromising the calcium phosphate deposit. This lack of oxygen can occur due to complications in childbirth, respiratory problems, renal problems that characterize an inadequate supply of calcium phosphate, diarrhea, malnutrition, and frequent childhood diseases with a history of high fever ${ }^{6,10,11,14,16}$.

In a study carried out by Fatturi ${ }^{16}$, there was a positive association between problems during pregnancy (high fever, stress and anxiety) and problems during delivery (hypoxia, high pressure) with enamel defects, as well as the study carried out by Jacobsen ${ }^{18}$, which found the relationship between enamel defects and medications during the pre-natal period. The data found in the present study disagree with the studies cited, since only five children presented problems during delivery (prolonged delivery, premature delivery, hypoxia) associated with enamel defects, however, these results can be explained by the small number of children included in the present study.

Several studies state that respiratory problems (asthma, bronchitis, sinusitis and rhinitis) and fever are related to enamel malformation $13,7,9,10,16$. A study carried out by Gurgolette ${ }^{19}$ showed a high prevalence of enamel defects, estimating an increase in the risk of enamel defects by 11 times in permanent dentition.

According to data found by Allazam ${ }^{1}$, a study carried out with 267 children aged 8 to 12 years showed high significance in patients with incisive molar hypo mineralization and history of diseases up to four years of age, among the diseases asthma, adenoiditis, tonsillitis, fever and high intake of antibiotics were included. Thus, the data found in this study are in agreement with the authors, and most children with enamel defects presented some respiratory problems up to the age of three years.

The difficulty of evaluating incomplete records of UEM Dentistry Clinic was a limiting factor, reducing the number of the sample.

Enamel defects are associated with various health problems, so a good anamnesis should be performed and the dental surgeon should be attentive to relate diseases to dental problems. Therefore, other studies should be carried out evaluating the association between other diseases and enamel defects.

\section{Conclusion}

It is concluded, therefore, that the presence of respiratory problems in early childhood, can interfere in amelogenesis, providing disturbances for the formation of normal enamel, causing defects or irregularities in the surface of the dental enamel, such as hypoplasias and hypo mineralization.

\section{Acknowledgments}

To CNPq and Fundação Araucária for the encouragement and opportunity to research.

\section{References}

1. Allazzam SM, Alaki SM, El Meligy OA. Molar incisor hypo mineralization, prevalence, and etiology. Int J Dent 2014;1-8. doi: $10.1155 / 2014 / 234508$

2. Robles MJ, Ruiz M, Bravo-Perez M, González E, Peñalver MA. Prevalence of enamel defects in primary and permanent teeth in a group of schoolchildren from Granada (Spain). Med Oral Patol Oral Cir Bucal 2013;18(2):187-93. doi: 10.4317/ medoral. 18580

3. Masumo R, Bårdsen A, Astrøm AN. Developmental defects of enamel in primary teeth and association with early life course events: a study of 6-36 month old children in Manyara, Tanzania. BMC Oral Health 2013;13:21. doi: 10.1186/14726831-13-21

4. Lunardelli SE, Peres MA. Prevalence and distribution of developmental enamel defects in the primary dentition of pre-school children Prevalência e distribuição de defeitos de desenvolvimento de esmalte na dentição decídua de préescolares. Braz Oral Res 2005;19(2):144-9. doi: 10.1590/ S1806-83242005000200013

5. Mcdonald RE, Avery DR, Dean JA. Odontopediatria para crianças e adolescentes. Rio de Janeiro: Elsevir; 2011.

6. Crombie FA, Manton DJ, Palamara JE, Zalizniak I, Cochrane NJ. Reynolds EC. Characterisation of developmentally hypomineralised human enamel. J Dent 2013;41(7):611-8. doi: 10.1016/j.jdent.2013.05.002.

7. Elfrink MEC, Schuller AA, Veerkamp JSJ, Moll HA, ten Cate JM. Factors increasing the caries risk of second primary molars in 5-year-old Dutch children. Int J Paediatr Dent 2010;20:151-57.

8. Kühnisch J, Mach D, Thiering E, Brockow I, Hoffmann U, Neumann C, et al. Respiratory diseases are associated with molar-incisor hypomineralizations Results from a long-term prospective cohort study. SWISS Dent J 2014;124(3):286-93.

9. Silva MJ, Scurrah KJ, Craig JM, Manton DJ, Kilpatrick N. Etiology of molar incisor hypo mineralization: a systematic review. Community Dent Oral Epidemiol 2016;44(4):342-53. doi: 10.1111/cdoe.12229

10. Andrade NS, Dos Santos IT, Lima LMS, et al. Impact of Developmental enamel defects on quality of life in 5-yearold children. Int J Paediatr Dent 2019;29(5):557-65. doi: 10.1111/ipd.12498

11. Serna Muñoz C, Pérez Silva A, Solano F, Castells MT, Vicente A, Ortiz Ruiz AJ. Effect of antibiotics and NSAIDs on cyclooxygenase- 2 in the enamel mineralization. Sci Rep 2018;8(1):4132. doi: 10.1038/s41598-018-22607-z 
12. Salanitri S, Seow WK. Developmental enamel defects in the primary dentition: aetiology and clinical management. Aust Dent J 2013;58(2):133-266. doi: 10.1111/adj.12039

13. Garib DG, Alencar BM, Ferreira FV, Ozawa TO. Anomalias dentárias associadas: o ortodontista decodificando a genética que rege os distúrbios de desenvolvimento dentário. Dent Press J Orthod 2010;15(2):138-57. doi: 10.1590/s217694512010000200017

14. Schwendicke F, Elhennawy K, Reda S, Bekes K, Manton DJ, Krois J. Global burden of molar incisor hypo mineralization. J Dent 2019;80:89-92 doi: 10.1016/j.jdent.2017.12.002

15. A review of the developmental defects of enamel index (DDE Index). Commission on Oral Health, Research \& Epidemiology. Report of an FDI Working Group. Int Dent J 1992;42(6):411-26.

16. Fatturi AL, Wambier LM, Chibinski AC, et al. A systematic review and meta-analysis of systemic exposure associated with molar incisor hypo mineralization. Community Dent Oral Epidemiol 2019;47(5):407-15. doi:10.1111/cdoe.12467

17. Teixeira RJPB, Andrade NS, Queiroz LCC, et al. Exploring the association between genetic and environmental factors and molar incisor hypo mineralization: evidence from a twin study. Int J Paediatr Dent 2018;28(2):198-206. doi:10.1111/ ipd. 12327

18. Jacobsen PE, Henriksen TB, Haubek D, Ostergaard JR. Developmental enamel defects in children prenatally exposed to anti-epileptic drugs. PLoS One 2013;8(3):e58213. doi: 10.1371/journal.pone.0058213

19. Guergolette RP, Dezan CC, Frossard WT, Ferreira FB, Cerci Neto A, Fernandes KB. Prevalence of developmental defects of enamel in children and adolescents with asthma. J Bras Pneumol 2009;35(4):295-300. doi: 10.1590/s180637132009000400002 